\title{
Protein from Hevea brasiliensis "Hev b 13" latex attenuates systemic inflammatory response and lung lesions in rats with sepsis
}

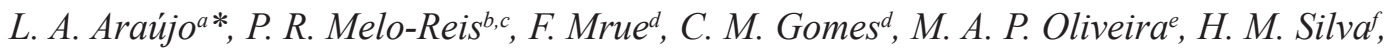 \\ M. M. Alves ${ }^{c}$ and N. J. Silva-Júnior ${ }^{c, d}$
}

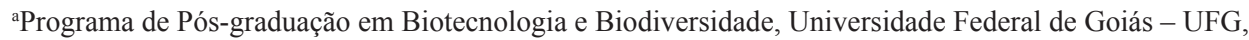
Campus Samambaia, ICB IV, Av. Esperança, Setor Itatiaia, CEP 74001-970, Goiânia, GO, Brazil

${ }^{b}$ Laboratório de Estudos Experimentais e Biotecnológicos - LEB, Departamento de Biomedicina e Farmácia, Pontifícia Universidade Católica de Goiás - PUC Goiás, Campus I, Área V, Setor Universitário, CEP 74605-140, Goiânia, GO, Brazil

'Programa de Pós-graduação em Ciências Ambientais e Saúde, Pontifícia Universidade Católica de Goiás - PUC Goiás, Área V, Setor Universitário, CEP 74605-140, Goiânia, GO, Brazil

${ }^{\text {d} D e p a r t a m e n t o ~ d e ~ M e d i c i n a, ~ P o n t i f i ́ c i a ~ U n i v e r s i d a d e ~ C a t o ́ l i c a ~ d e ~ G o i a ́ s ~-~ P U C ~ G o i a ́ s, ~ A ́ r e a ~ I V, ~ C a m p u s ~ I, ~}$ Setor Universitário, CEP 74605-010, Goiânia, GO, Brazil

'Instituto de Patologia Tropical e Saúde Pública, Universidade Federal de Goiás - UFG, Setor Universitário, CEP 74605-050, Goiânia, GO, Brazil

fFaculdade de Medicina, Centro Universitário - UNIRG, Campus II, Centro, CEP 77403-090, Gurupi, TO, Brazil

*e-mail: lilhianalves@gmail.com

Received: April 28, 2016 - Accepted: November 28, 2016 - Distributed: May 31, 2018

(With 3 figures)

\begin{abstract}
Sepsis induces a severe systemic inflammatory response that may result in multiple organ dysfunction and death. Studies using a protein derived from natural Hevea brasiliensis (rubber tree) latex, denominated Hev b 13, have demonstrated important anti-inflammatory effects, but no data have been published regarding its effects on sepsis. The aim of this study was to investigate the effects of Hev b 13 on the inflammatory response and lung lesions of septal rats. Male Wistar rats were submitted to cecal ligation and puncture (CLP), randomized into groups and treated with subcutaneously administered doses of $0.5 / 2.0 / 3.0 \mathrm{mg} / \mathrm{Kg}$ of $\mathrm{Hev}$ b 13. Next, animals were subdivided into three different points in time (1, 6 and 24 hours after treatments) for collection of blood samples and euthanasia accompanied by organ removal. Total and differential leukocyte counts, cytokine dosage and histological assessment were analyzed. Treatment with Hev b 13 resulted in a significant decline in total and differential leukocytes as well as suppression of TNF- $\alpha$ and IL-6 production, associated with the increase in IL-10 and IL-4 in plasma and lung tissue. Moreover, it reduced morphological and pathological changes found in the lungs, including neutrophil infiltration, edema and alveolar thickening. The present study concluded that Hev b 13 exerts anti-inflammatory effects and attenuates lung lesions in septal rats, showing potential for clinical application.
\end{abstract}

Keywords: Hev b 13, Hevea brasiliensis, inflammatory response, sepsis.

\section{Proteína do latex de Hevea brasiliensis "Hev b 13" atenua resposta inflamatória sistêmica e lesão pulmonar de ratos com sepse}

\section{Resumo}

Sepse induz uma resposta inflamatória sistêmica grave podendo resultar em disfunção de múltiplos órgãos e morte. Pesquisas utilizando uma proteína derivada do látex natural de Hevea brasiliensis (seringueira), denominada Hev b 13 tem demonstrado importantes efeitos anti-inflamatórios, mas nenhum dado foi publicado dos seus efeitos na sepse. O objetivo deste estudo foi investigar os efeitos da Hev b 13 na resposta inflamatória e na lesão pulmonar de ratos com sepse. Ratos machos da linhagem Wistar foram submetidos a ligação e perfuração do ceco (LPC), randomizados em grupos e tratados com as doses $0,5 / 2,0 / 3,0 \mathrm{mg} / \mathrm{Kg}$ de Hev b 13 subcutâneo. Após subdividiu-se os animais em três pontos diferentes de tempo (1, 6 e 24 horas após os tratamentos) para coleta de amostras sanguíneas e eutanásia com remoção dos órgãos. Contagem total e diferencial de leucócitos, dosagem de citocinas e avaliação histológica foram analisadas. $\mathrm{O}$ tratamento com a Hev b 13 resultou em diminuição significativa de leucócitos totais e diferenciais bem como suprimiu a produção de TNF- $\alpha$ e IL-6, associado ao aumento de IL-10 e IL-4 no plasma e tecido pulmonar. 
Além disso, reduziu as alterações morfológicas e patológicas encontradas nos pulmões, incluindo infiltrado de neutrófilos, edema e espessamento alveolar. Este estudo concluiu que a Hev b 13 tem efeitos anti-inflamatórios e atenua lesões pulmonares em ratos com sepse, apresentando potencialidades para aplicabilidade clínica.

Palavras-chave: Hev b 13, Hevea brasiliensis, resposta inflamória, sepse.

\section{Introduction}

Sepsis is defined as life-threatening organ dysfunction caused by a dysregulated host response to infection (Shankar-Hari et al., 2016). Despite recent advances in surgical techniques and intensive medicine, global mortality of patients with sepsis remains high, ranging between $30 \%$ and $50 \%$. Sepsis, responsible for 200,000 deaths per year in the United States, has become the primary cause of death in hospitals in the $21^{\text {st }}$ century (Iwashyna et al., 2012; Kaukonen et al., 2014).

During the development of sepsis, bacterial components activate transmembrane recognition proteins, also called toll like receptors (TLRs), which recognize pathogen-associated molecular patterns (PAMPs). These initiate an immunological cascade resulting in the release of pro-inflammatory interleukins, including the tumor necrosis factor (TNF- $\alpha$ ), interleukin (IL) 1, IL-2, IL-6, IL-8, and IL-12, among others (Cai et al., 2016). Overproduction of these inflammatory mediators (cytokine storm) induces vasodilation, increased capillary permeability, hypotension, hemoconcentration, macromolecular leakage and edema, and may lead to multiple organ dysfunction syndrome (MODS), where the lungs are the most frequently affected (Matsuda and Hattori, 2006; Stearns-Kurosawa et al., 2011; Ates et al., 2015).

The response of the host to pathogenic agents must be strictly regulated since the consequences of exacerbated inflammation may be more lethal than the original pathogenic aggression itself. In addition to the intense pro-inflammatory activity, anti-inflammatory interleukins IL-4, IL-5, IL-10, IL-11 and IL-13 are also produced. These are directly implicated in the weakening of responses to etiological agents, generating the compensatory anti-inflammatory response syndrome (CARS) (Ward, 2011). This is more intense in situations where the patient survives the disturbances related to systemic inflammation (Gomes et al., 2016).

To date, there are no effective drugs on the market to counterbalance the acute inflammatory response. One of the promising therapies for sepsis is recombinant human activated protein $\mathrm{C}$ (drotrecogin alfa). Despite being a potent anticoagulant and its recognized anti-inflammatory role in reducing lethality when administered early in patients with high risk of death, its effectiveness was questioned after the occurrence of serious hemorrhagic episodes (Ranieri et al., 2012). Thus, new therapeutic approaches that might decrease mortality associated with this serious condition are highly valuable.

Hev b 13, a protein derived and purified from Hevea brasiliensis latex, was capable of potentiating human mononuclear cells in the presence of phytohemagglutinin, to produce IL- 10 and TGF- $\beta$. Furthermore, it inhibited TNF- $\alpha$, IL- $1 \beta$ and IL- 6 production (Teixeira et al., 2012a). In other experiments using animal models of ulcerative colitis and rheumatoid arthritis, treatment with the Hev b 13 fraction demonstrated an important regression of the lesions under study (Teixeira et al., 2012a, b). The ability of Hev b 13 to inhibit pro-inflammatory and stimulate anti-inflammatory cytokine production suggests that this protein may modulate systemic inflammatory response syndrome - SIRS. Thus, the aim of this study was to investigate the effects of Hev b 13 on inflammatory response, as well as its repercussion on pulmonary dysfunction in rats with experimentally-induced acute sepsis.

\section{Material and Methods}

\subsection{Obtaining protein $\mathrm{Hev} b$}

The protein fraction Hev b 13, derived from the serum of Hevea brasiliensis latex, was kindly donated by the Pele Nova Biotechnology Laboratory in Ribeirão Preto, São Paulo state, Brazil (batch no. 1502-243).

\subsection{Experimental animals}

Adult male Wistar Rattus norvegicus albinus rats, weighing between 200 and 300 grams, obtained from the Central Vivarium of the Pontifical Catholic University of Goiás (PUC Goiás), were used. The experiment, which followed international guidelines and those of the Brazilian Society of Laboratory Animal Sciences (SBCAL), was approved by the Animal Ethics Committee of PUC Goiás under protocol no. 0008/1.

\subsection{Sepsis induction by cecal ligation and puncture (CLP)}

The animals were intramuscularly anesthetized in the anterior surface of the right thigh with a mixture of $2 \%$ xylazine hydrochloride $(2.5 \mathrm{mg} / \mathrm{kg})$ and $10 \%$ ketamine hydrochloride $(50 \mathrm{mg} / \mathrm{kg}$ - Syntec - São Paulo - Brazil), and then submitted to midline laparotomy with a 1 -cm-long incision to expose the cecum and adjacent areas. Next, cecal ligation was performed with a 3.0 silk thread at the base, below the ileocecal valve, and punctured twice with a 14- gauge needle. The cecum was then pressed to induce fecal evacuation through the punctured area and returned to the peritoneal cavity. The abdominal wall was sutured in two layers with 4.0 mononylon and simple running sutures (Abd El-Latif et al., 2016). Finally, hydration was performed with a single subcutaneous $5 \mathrm{~mL}$ dose of Ringer's lactate and the animals were returned to their cages, fed the appropriate ration for the species and given water ad libitum. 


\subsection{Groups and treatments}

Randomization was carried out 6 hours after sepsis-induced surgery in 4 groups: rats submitted to cecal ligation and puncture and treated only with $0.9 \%$ saline solution (CLP control group); rats submitted to CLP and treated with a single dose of $0.5 \mathrm{mg} / 2.0 \mathrm{mg} /$ and $3.0 \mathrm{mg} / \mathrm{Kg}$ of protein Hev b 13 (groups Hev b 13 dose $0.5 / 2.0$ and $3.0 \mathrm{mg} / \mathrm{Kg}$ ). The animals were then subdivided into three different points in time (1, 6 and 24 hours after the treatments), for anesthesia and blood collection via cardiac puncture, followed by euthanasia and removal of the lungs. The same biological material was also collected from healthy animals to obtain reference values.

\subsection{Leukogram}

Blood samples were diluted in Turk's solution (Audaz Reagentes Tecnológicos - São Paulo - Brazil) and pipetted in a Neubauer chamber for visualization and total leukocyte count under optical microscope (Nikon, Eclipse E - 400X magnification). For differential counting, swabs of new blood samples were taken and stained with Panótico (Laborclin - Paraná - Brazil) to identify leukocytes by their morphological specificities.

\subsection{Cytokine detection}

\subsubsection{Plasma preparation}

The blood collected was deposited in tubes with ethylenediamine tetraacetic acid (EDTA) and centrifuged at $1000 \mathrm{rpm}$, for 30 minutes at a temperature of $4{ }^{\circ} \mathrm{C}$ to separate the plasma, then aliquoted and stored in a freezer at $-80^{\circ} \mathrm{C}$ until dosing.

\subsubsection{Preparation of tissue samples}

Fragments of lung were removed and weighed on a precision scale, stored in tubes with $200 \mu \mathrm{L}$ of $1 \mathrm{X}$ phosphate buffered saline (PBS) and 1\% protease inhibitor (Sigma - Missouri - USA), and kept in the freezer at $-80{ }^{\circ} \mathrm{C}$ until dosing. The tubes were thawed and added with $15 \mathrm{~mL} / \mathrm{mg}$ of $1 \mathrm{X}$ PBS and 10\% lysis buffer (Tris buffer - $100 \mathrm{mM}$ Tris - HCL, 1.5 M NaCl, 10\% TRITON X-100, 50 mM EDTA), manually macerated, homogenized using an Ultra Stirrer (Scientific SDN BHD, Ehsan, Malaysia) and then centrifuged at 10,000 rpm (Gokcinar et al., 2013). The supernatant from the macerate was used for doses.

\subsubsection{Enzyme-linked immunosorbent assay (Elisa)}

The concentrations of TNF- $\alpha$, IL-6, IL-10 and IL4 were determined using immunoenzymatic assay kits (BDBiosciences), according to manufacturer's recommendations. All the plasma and supernatant samples were measured in duplicate.

\subsection{Histological analysis}

Lungs were immersed in 10\% buffered formalin and routinely included in paraffin. Strips of tissue were cut at a thickness of $5 \mu \mathrm{m}$, mounted on slides and stained with hematoxylin-eosine. The slides $(n=8)$ were examined by an experienced pathologist blind to the treatments, under a light microscope using 200X magnification (100 fields per section). Lung tissue lesions were classified as (0) normal ( $0 \%$ of the area); (1) mild (25\%); (2) moderate $(50 \%)$; (3) significant $(75 \%),(4)$ severe $(100 \%)$ in the following categories: neutrophil infiltration, interstitial edema, hyperemia, hemorrhage, thickening and necrosis. The sum of the scores obtained in each category was used in semiquantitative analysis (Zhou et al., 2015).

\subsection{Statistical analysis}

Statistics were analyzed using the GraphPad Prism 6.05 program (San Diego, CA, USA), and the results presented as mean \pm standard deviation. Analysis of variance (ANOVA) and Tukey's test were used to check for significant leukogram and cytokine level differences. The Kruskal-Wallis test was used to compare histological categories. A significance level of $\mathrm{p}<0.05$ was adopted for all analyses.

\section{Results}

\subsection{Effects of treatment with Hev b 13 on the leukogram}

The animals submitted to CLP (CLP control) exhibited progressive leukocytosis in accordance with sepsis evolution. However, the increase in total, mature and basophil leukocytes in the groups treated with Hev b 13 at all doses $(0.5 / 2.0 / 3.0 \mathrm{mg} / \mathrm{kg})$ was significantly lower than in the CLP control group after 1 hour of treatment $(\mathrm{p}<0.05$; Table 1). The same occurred in nearly all leukocyte types at 6 and 24 hours, except for eosinophils (Tables 2 and 3). There was no significant difference in leukocyte values among the treatments.

\subsection{Efjects of Hev b 13 on plasma cytokines}

\subsubsection{TNF- $\alpha$ and IL-6}

Analysis of CLP controls, whose animals were not treated, showed that plasma levels of TNF- $\alpha$ reached their production peak in 1 hour, declining according to sepsis evolution (Figures 1A, B and C). In animals treated with doses of 2.0 and $3.0 \mathrm{mg} / \mathrm{kg}$ of Hev b 13, there was a significant reduction in TNF- $\alpha$ levels in relation to CLP controls after 1 and 6 hours of treatment ( $<<0.05$; Figure 1A, B). No significant difference was observed between doses in terms of reducing TNF- $\alpha$ levels. IL- 6 exhibited its production peak at 6 hours (Figure 1D, E and F), and was significantly lower after treatment with all doses of Hev b $13(\mathrm{p}<0.05)$. At the other times, there was no significant reduction in IL-6 (Figure 1D and F).

\subsubsection{IL-10 and IL-4}

The production peak of IL-10 was detected at 6 hours (CLP control in Figure $1 \mathrm{G}, \mathrm{H}$ and I). After treatment with $2.0 \mathrm{mg} / \mathrm{kg}$ of Hev b 13, the plasma levels of IL-10 rose significantly in relation to CLP control at 1 and 24 hours $(\mathrm{p}<0.05$; Figure $1 \mathrm{G}$ and I). At all times, the $2.0 \mathrm{mg} / \mathrm{Kg}$ dose was more active in increasing IL-10 production than the other treatments (Figure $1 \mathrm{G}, \mathrm{H}$ and I). Finally, the dose 
Table 1. Leukogram of the different groups 1 hour after treatments.

\begin{tabular}{|c|c|c|c|c|c|}
\hline \multirow{2}{*}{$\begin{array}{l}\text { Parameters } \\
\left(10^{3} \mu \mathrm{L}\right)\end{array}$} & \multirow{2}{*}{ Normal } & \multirow{2}{*}{ CLP control } & \multicolumn{3}{|c|}{ Hev b 13} \\
\hline & & & $0.5 \mathrm{mg}$ & $2.0 \mathrm{mg}$ & $3.0 \mathrm{mg}$ \\
\hline \multicolumn{6}{|l|}{ Total Leukocytes } \\
\hline Mean $( \pm \mathrm{SD})$ & $3,290( \pm 388)$ & $7,800( \pm 1,586)$ & $4,781( \pm 1,800)^{*}$ & $3,000( \pm 875)^{*}$ & $3,660( \pm 1,177)^{*}$ \\
\hline Variation & $2,900-3,800$ & $5,450-8,850$ & $2,300-7,400$ & $1,600-4,350$ & $2,550-5,150$ \\
\hline \multicolumn{6}{|l|}{ Mature } \\
\hline \multicolumn{6}{|l|}{ Neutrophils } \\
\hline Mean $( \pm \mathrm{SD})$ & $1,357( \pm 215)$ & $5,418( \pm 1,220)$ & $2,381( \pm 970)^{*}$ & $1,182( \pm 321)^{*}$ & $2,201( \pm 845)^{*}$ \\
\hline Variation & $1,064-1,580$ & $4,033-6,660$ & $989-3,623$ & $768-1,677$ & $1,275-3,193$ \\
\hline \multicolumn{6}{|l|}{ Immature } \\
\hline \multicolumn{6}{|l|}{ Neutrophils } \\
\hline Mean $( \pm \mathrm{SD})$ & $482( \pm 278)$ & $839( \pm 476)$ & $1,135( \pm 643)$ & $879( \pm 322)$ & $431( \pm 201)$ \\
\hline Variation & $217-874$ & $383-1,485$ & $391-2,294$ & $320-1,197$ & $282-773$ \\
\hline \multicolumn{6}{|l|}{ Lymphocytes } \\
\hline Mean $( \pm \mathrm{SD})$ & $1,341( \pm 304)$ & $1,135( \pm 541)$ & $1,054( \pm 364)$ & $770( \pm 448)$ & $865( \pm 313)$ \\
\hline Variation & $986-1,710$ & $692-1,816$ & $648-1,742$ & $367-1,566$ & $390-1,269$ \\
\hline \multicolumn{6}{|l|}{ Eosinophils } \\
\hline Mean $( \pm$ SD $)$ & $0( \pm 0)$ & $78( \pm 72)$ & $44( \pm 42)$ & $36( \pm 31)$ & $35( \pm 21)$ \\
\hline Variation & $0-0$ & $0-173$ & $0-129$ & $0-87$ & $0-51$ \\
\hline \multicolumn{6}{|l|}{ Monocytes } \\
\hline Mean $( \pm \mathrm{SD})$ & $42( \pm 22)$ & $200( \pm 126)$ & $115( \pm 102)$ & $72( \pm 33)$ & $67( \pm 30)$ \\
\hline Variation & $29-76$ & $82-346$ & $23-345$ & $32-131$ & $29-103$ \\
\hline \multicolumn{6}{|l|}{ Basophils } \\
\hline Mean $( \pm \mathrm{SD})$ & $50( \pm 22)$ & $126( \pm 48)$ & $50( \pm 15)^{*}$ & $60( \pm 17)^{*}$ & $58( \pm 28)^{*}$ \\
\hline Variation & $29-76$ & $82-173$ & $27-74$ & $32-87$ & $25-103$ \\
\hline
\end{tabular}

SD: Standard Deviation; $\mathrm{CLP}=\mathrm{Cecal}$ Ligation and Puncture; *Significant difference $(\mathrm{p}<0.05)$ in relation to the CLP control group compared by the ANOVA and Tukey's tests; Normal: Values exhibited only as reference and not included in the statistical analysis.

Table 2. Leukogram of different groups 6 hours after treatments.

\begin{tabular}{|c|c|c|c|c|c|}
\hline \multirow{2}{*}{$\begin{array}{c}\text { Parameters } \\
\left(10^{3} \mu \mathrm{L}\right)\end{array}$} & \multirow{2}{*}{ Normal } & \multirow{2}{*}{ CLP control } & \multicolumn{3}{|c|}{ Hev b 13} \\
\hline & & & $0.5 \mathrm{mg}$ & $2.0 \mathrm{mg}$ & $3.0 \mathrm{mg}$ \\
\hline \multicolumn{6}{|l|}{ Total leukocytes } \\
\hline Mean $( \pm$ SD $)$ & $3,290( \pm 388)$ & $9,087( \pm 487)$ & $3,650( \pm 917)^{*}$ & $3,171( \pm 844)^{*}$ & $3,470( \pm 568)^{*}$ \\
\hline Variation & $2,900-3,800$ & $8,600-9,750$ & $2,150-4,750$ & $2,040-4,500$ & $2,600-4,050$ \\
\hline \multicolumn{6}{|l|}{ Mature } \\
\hline \multicolumn{6}{|l|}{ Neutrophils } \\
\hline Mean $( \pm \mathrm{SD})$ & $1,357( \pm 215)$ & $5,625( \pm 905)$ & $1,802( \pm 497)^{*}$ & $1,526( \pm 515)^{*}$ & $1,873( \pm 434)^{*}$ \\
\hline Variation & $1,064-1,580$ & $4,628-6,825$ & $1,076-2,517$ & $837-2,385$ & $1,222-2,277$ \\
\hline \multicolumn{6}{|l|}{ Immature } \\
\hline \multicolumn{6}{|l|}{ Neutrophils } \\
\hline Mean $( \pm \mathrm{SD})$ & $482( \pm 278)$ & $1,549( \pm 517)$ & $724( \pm 285)^{*}$ & $816( \pm 235)^{*}$ & $823( \pm 190)^{*}$ \\
\hline Variation & $217-874$ & $877-2,136$ & $419-1,118$ & $472-1,170$ & $547-113$ \\
\hline \multicolumn{6}{|l|}{ Lymphocytes } \\
\hline Mean $( \pm$ SD $)$ & $1,341( \pm 304)$ & $1,456( \pm 364)$ & $955( \pm 411)$ & $687( \pm 254)^{*}$ & $651( \pm 239)^{*}$ \\
\hline Variation & $986-1,710$ & $946-1,780$ & $495-1,860$ & $328-943$ & $379-1,013$ \\
\hline \multicolumn{6}{|l|}{ Eosinophils } \\
\hline Mean $( \pm \mathrm{SD})$ & $0( \pm 0)$ & $66( \pm 44)$ & $34( \pm 33)$ & $31( \pm 30)$ & $46( \pm 33)$ \\
\hline Variation & $0-0$ & $0-91$ & $0-93$ & $0-89$ & $0-81$ \\
\hline \multicolumn{6}{|l|}{ Monocytes } \\
\hline Mean $( \pm \mathrm{SD})$ & $42( \pm 22)$ & $252( \pm 99)$ & $70( \pm 35)^{*}$ & $61( \pm 18)^{*}$ & $29( \pm 16)^{*}$ \\
\hline Variation & $29-76$ & $178-390$ & $21-139$ & $41-89$ & $0-40$ \\
\hline \multicolumn{6}{|l|}{ Basophils } \\
\hline Mean $( \pm$ SD $)$ & $50( \pm 22)$ & $136( \pm 54)$ & $62( \pm 30) *$ & $48( \pm 14)^{*}$ & $46( \pm 13)^{*}$ \\
\hline Variation & $29-76$ & $89-195$ & $21-95$ & $20-61$ & $34-67$ \\
\hline
\end{tabular}

SD: Standard Deviation; $C L P=$ Cecal Ligation and Puncture; *Significant difference $(p<0.05)$ in relation to the CLP control group compared by the ANOVA and Tukey's tests; Normal: Values exhibited only as reference and not included in the statistical analysis. 
Table 3. Leukogram of the different groups 24 hours after treatments.

\begin{tabular}{|c|c|c|c|c|c|}
\hline \multirow{2}{*}{$\begin{array}{c}\text { Parameters } \\
\left(10^{3} \mu \mathrm{L}\right)\end{array}$} & \multirow{2}{*}{ Normal } & \multirow{2}{*}{ CLP control } & \multicolumn{3}{|c|}{ Hev b 13} \\
\hline & & & $0.5 \mathrm{mg}$ & $2.0 \mathrm{mg}$ & $3.0 \mathrm{mg}$ \\
\hline \multicolumn{6}{|l|}{ Total } \\
\hline \multicolumn{6}{|l|}{ Leukocytes } \\
\hline Mean $( \pm \mathrm{SD})$ & $3,290( \pm 388)$ & $12,716( \pm 1,501)$ & $4,212( \pm 764)^{*}$ & $3,966( \pm 541)^{*}$ & $4,114( \pm 855)^{*}$ \\
\hline Variation & $2,900-3,800$ & $10,600-14,550$ & $2,700-5,300$ & $3,050-4,650$ & $3,000-5,050$ \\
\hline \multicolumn{6}{|l|}{ Mature } \\
\hline \multicolumn{6}{|l|}{ Neutrophils } \\
\hline Mean $( \pm \mathrm{SD})$ & $1,357( \pm 215)$ & $7,615( \pm 1,050)$ & $2,302( \pm 487)^{*}$ & $1,969( \pm 376)^{*}$ & $2,149( \pm 628) *$ \\
\hline Variation & $1,064-1,580$ & $6,572-9,022$ & $1,431-2,968$ & $1,495-2,604$ & $1,260-2,980$ \\
\hline \multicolumn{6}{|l|}{ Immature } \\
\hline \multicolumn{6}{|l|}{ Neutrophils } \\
\hline Mean $( \pm$ SD $)$ & $482( \pm 278)$ & $1,919( \pm 255)$ & $531( \pm 214)^{*}$ & $473( \pm 132)^{*}$ & $592( \pm 193)^{*}$ \\
\hline Variation & $217-874$ & $1,599-2,226$ & $332-979$ & $279-622$ & $372-966$ \\
\hline \multicolumn{6}{|l|}{ Lymphocytes } \\
\hline Mean $( \pm \mathrm{SD})$ & $1,341( \pm 304)$ & $2,715( \pm 717)$ & $1,213( \pm 276)^{*}$ & $1,326( \pm 312)^{*}$ & $1,178( \pm 229)^{*}$ \\
\hline Variation & $986-1,710$ & $1,590-3,512$ & $837-1,615$ & $762-1,581$ & $806-1,392$ \\
\hline \multicolumn{6}{|l|}{ Eosinophils } \\
\hline Mean $( \pm \mathrm{SD})$ & $0( \pm 0)$ & $85( \pm 66)$ & $45( \pm 42)$ & $45( \pm 38)$ & $62( \pm 33)$ \\
\hline Variation & $0-0$ & $0-140$ & $0-106$ & $0-85$ & $0-101$ \\
\hline \multicolumn{6}{|l|}{ Monocytes } \\
\hline Mean $( \pm \mathrm{SD})$ & $42( \pm 22)$ & $212( \pm 70)$ & $61( \pm 20)^{*}$ & $79( \pm 38)^{*}$ & $54( \pm 45)^{*}$ \\
\hline Variation & $29-76$ & $106-281$ & $40-89$ & $37-125$ & $0-101$ \\
\hline \multicolumn{6}{|l|}{ Basophils } \\
\hline Mean $( \pm$ SD $)$ & $50( \pm 22)$ & $169( \pm 68)$ & $59( \pm 28)^{*}$ & $71( \pm 25)^{*}$ & $76( \pm 22)^{*}$ \\
\hline Variation & $29-76$ & $106-264$ & 27-106 & $37-94$ & $43-101$ \\
\hline
\end{tabular}

SD: Standard Deviation; CLP $=$ Cecal Ligation and Puncture; *Significant difference $(\mathrm{p}<0.05)$ in relation to the CLP control group compared by the ANOVA and Tukey's tests; Normal: Values exhibited only as reference and not included in the statistical analysis.

of IL-4 in plasma reached its production peak in 1 hour, and treatment with a dose of $2.0 \mathrm{mg} / \mathrm{Kg}$ was responsible for significantly increasing its concentrations in relation to CLP controls at all times ( $\mathrm{p}<0.05$; Figure $1 \mathrm{~J}$, L and M). The dose of $3.0 \mathrm{mg} / \mathrm{Kg}$ also significantly increased IL-4 concentrations compared to CLP controls, but only at a time of 1 hour (Figure $1 \mathrm{~J}$ ). Among the treatments, the $2.0 \mathrm{mg} / \mathrm{kg}$ dose was the most active in increasing IL-4 concentration, mainly when compared to the dose of $0.5 \mathrm{mg} / \mathrm{kg}$.

\subsection{Effects of Hev b 13 on lung tissue cytokines}

\subsubsection{TNF- $\alpha$ and IL-6}

In lung tissue, the results demonstrated that the production peak of TNF- $\alpha$ and IL- 6 occurred at 1 hour in the CLP groups (Figure 2A and D). After treatment with a dose of $2.0 \mathrm{mg} /$ $\mathrm{Kg}$, there was a significant decline in TNF- $\alpha$ levels at 1 and 24 hours ( $<<0.05$; Figure $2 \mathrm{~A}$ and C), and IL- 6 at 24 hours (Figure $2 \mathrm{~F}$ ). The $3.0 \mathrm{mg} / \mathrm{kg}$ dose also significantly reduced TNF- $\alpha$ and IL- 6 levels in relation to CLP controls, at all treatment times ( $p<0.05$; Figure $2 \mathrm{~A}, \mathrm{~B}, \mathrm{C}, \mathrm{D}, \mathrm{E}$ and $\mathrm{F})$. The $3.0 \mathrm{mg} / \mathrm{Kg}$ dose was more active in decreasing TNF- $\alpha$ and IL-6 production compared to $0.5 \mathrm{mg} / \mathrm{Kg}$ at practically all the times.

3.3.2. IL-10 and IL-4
In CLP controls, there was no minimum or maximum production peak for IL-10 in lung tissue, with similar production at all the times analyzed. However, IL-10 was significantly higher at a dose of $2.0 \mathrm{mg} / \mathrm{Kg}$ at all the times, when compared to CLP controls ( $p<0.05$; Figure $2 \mathrm{G}, \mathrm{H}$ and I). The production peak of IL-4 in lung tissue occurred at 6 and 24 hours, with a significant increase after treatment at a dose of $2.0 \mathrm{mg} / \mathrm{Kg}$ at all times ( $<<0.05$; Figure $2 \mathrm{~J}$, $\mathrm{L}$ and $\mathrm{M}$ ). The $3.0 \mathrm{mg} / \mathrm{Kg}$ dose also raised IL-4 tissue levels at 1 hour (Figure 2J).

\subsection{Effects of Hev b 13 on pulmonary histology}

In CLP controls a number of morphological changes were observed at the first time analyzed, including inflammatory cell infiltration, interstitial edema and lung congestion. These alterations increased gradually with the evolution of sepsis. However, treatments with Hev b 13 at doses of 2.0 and $3.0 \mathrm{mg} / \mathrm{Kg}$ significantly attenuated these histopathological lesions at 6 and 24 hours $(p<0.05$; Figure $3 \mathrm{~A}$ and $\mathrm{B}$ ).

\section{Discussion}

A number of animal models have been used to study the physiopathology of sepsis. The greatest challenge is to mimick the clinical complexity of human sepsis and test 

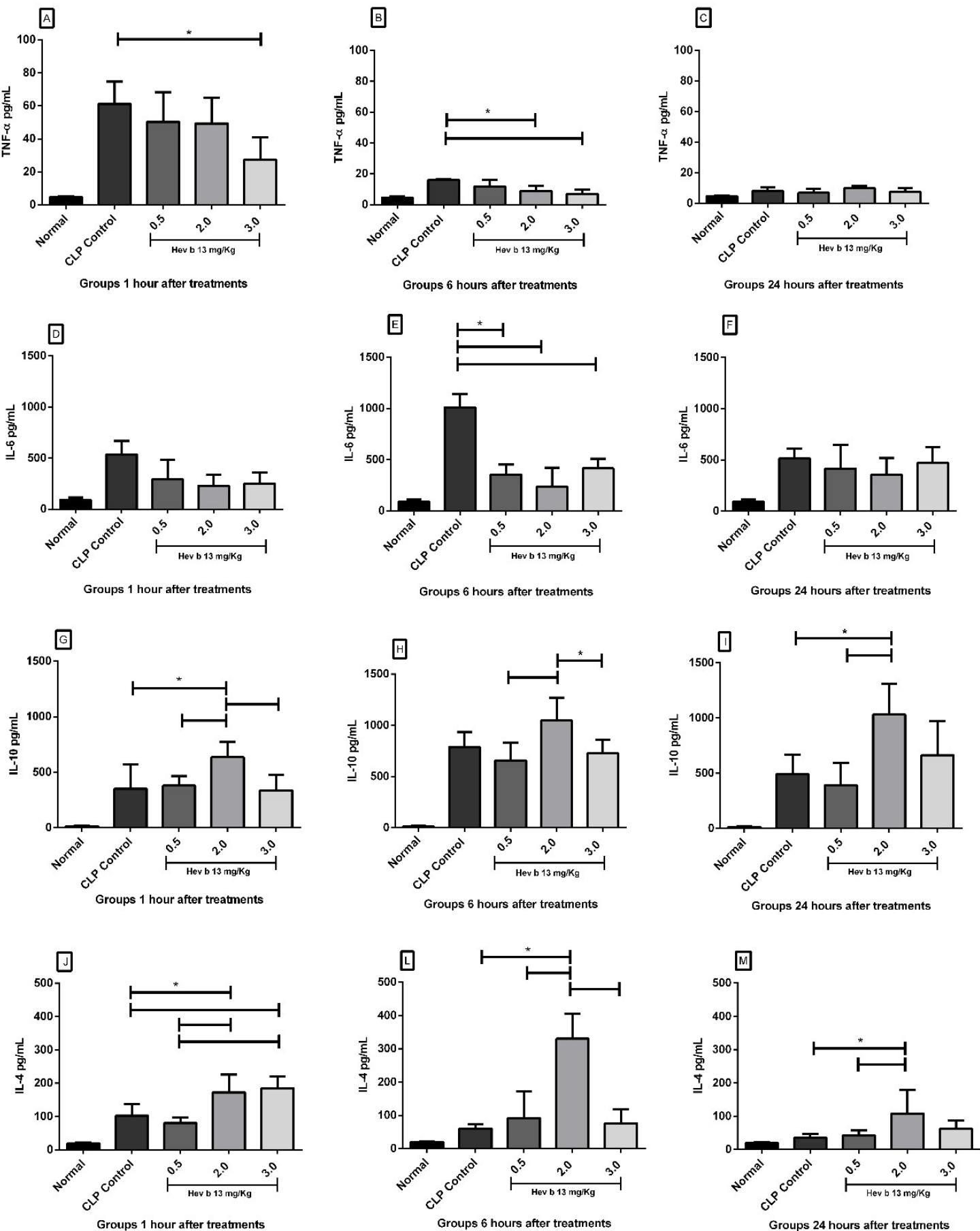

Figure 1. Effects of Hev b 13 on plasma cytokines of rats with sepsis. Six hours after cecal ligation and puncture (CLP), the animals were treated with Hev b 13 (doses: $0.5 / 2.0 / 3.0 \mathrm{mg} / \mathrm{Kg}$ ) and euthanized at 1,6 and 24 hours to collect blood samples and doses of TNF- $\alpha$, IL-6, IL-10 and IL-4. Data are presented as means \pm SD and expressed as pictograms of cytokines/ milliliter of plasma $(n=8) . *(p<0.05)$ indicates significant groups as analyzed by ANOVA followed by Tukey's test. The normal group is presented only as reference. 

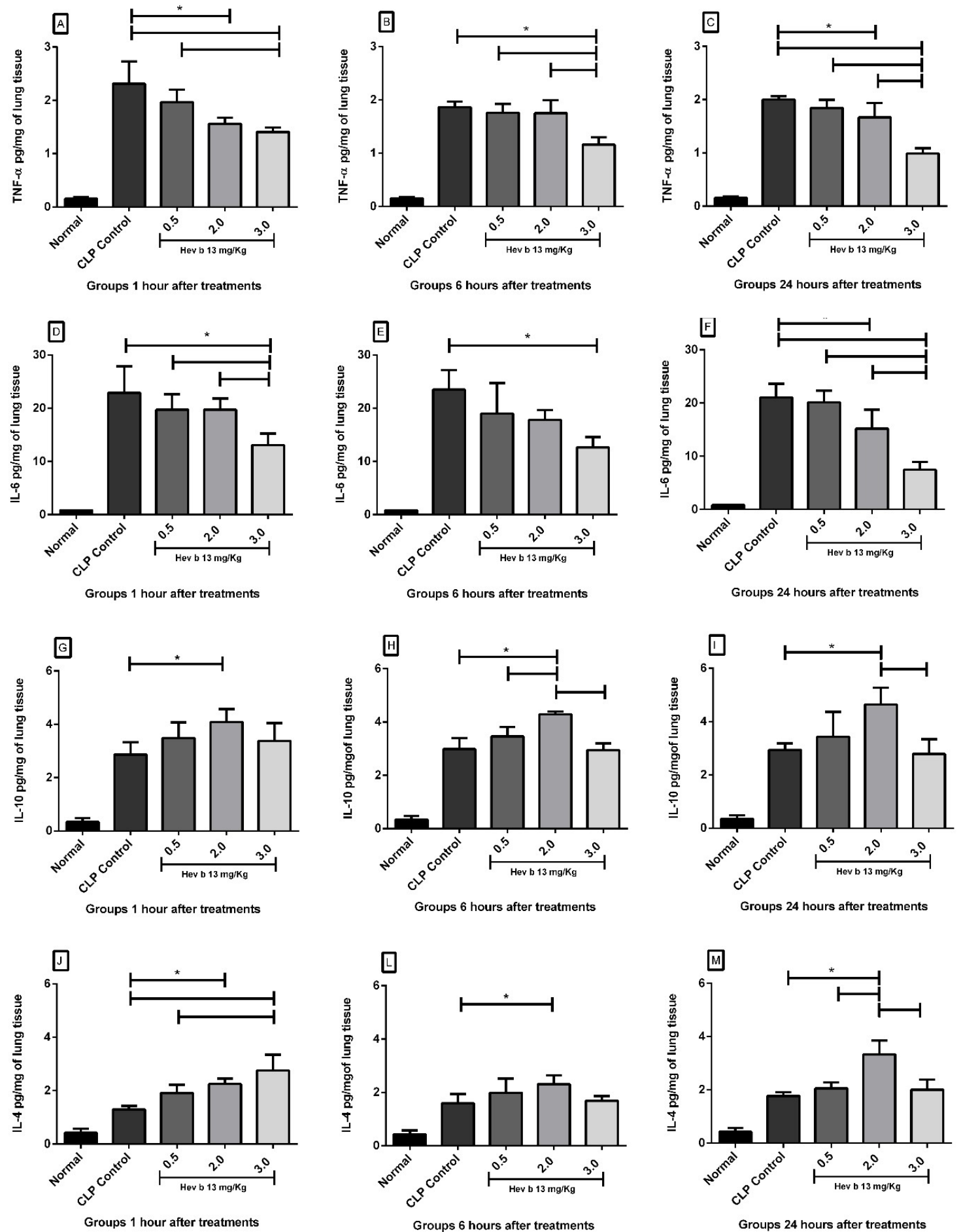

Figure 2. Effects of Hev b 13 on lung tissue cytokines in rats with sepsis. Six hours after cecal ligation and puncture (CLP), the animals were treated with Hev b 13 (doses: $0.5 / 2.0 / 3.0 \mathrm{mg} / \mathrm{Kg}$ ) and euthanized at 1,6 and 24 hours to collect blood samples and doses of TNF- $\alpha$, IL- 6 , IL-10 and IL-4. Data are presented as means \pm SD and expressed as pictograms of cytokines/milliliter of plasma $(\mathrm{n}=8) .{ }^{*}(\mathrm{p}<0.05)$ indicates significant groups as analyzed by ANOVA followed by Tukey's test. 


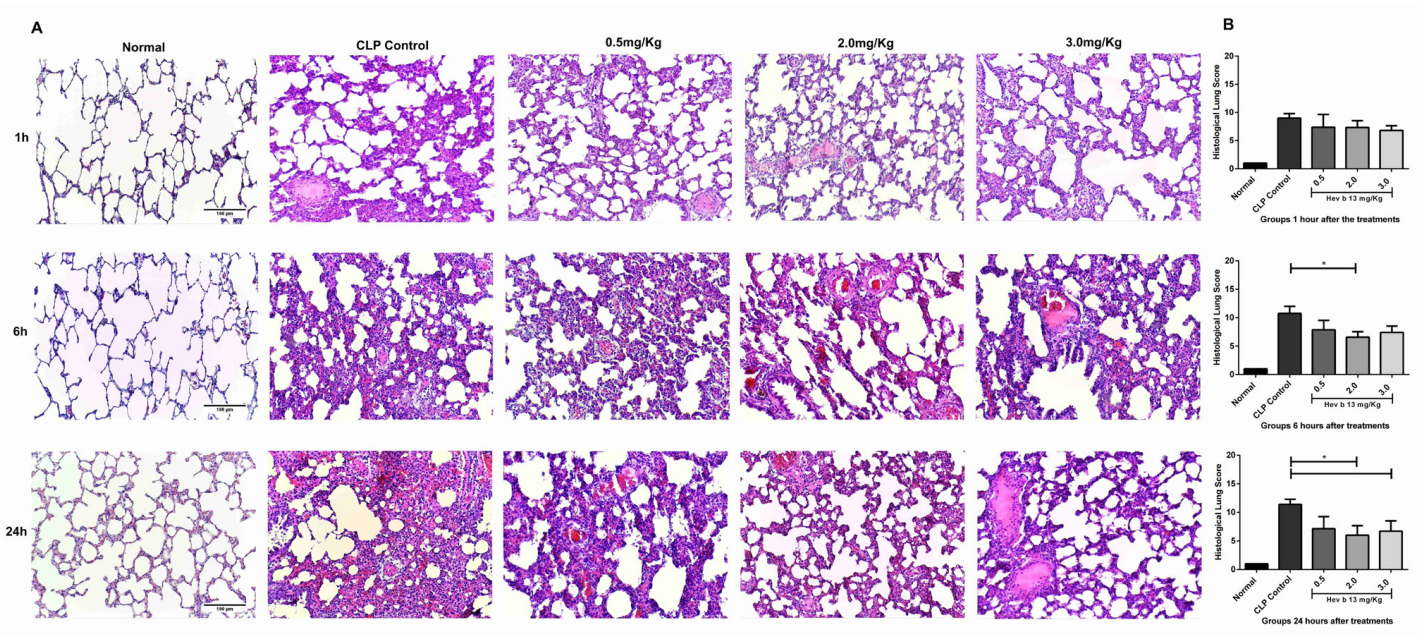

Figure 3. Effects of Hev b 13 on the pulmonary histology of rats with sepsis. (A) Lung tissue sections were stained with Hematoxylin-Eosin. The images were selected from the different experimental groups of time and doses, with normal images used only as reference (200x magnification; scale bar $100 \mu \mathrm{m})$; (B) Semiquantitative analysis of pulmonary lesions. Slides were assessed as: normal (0), mild (1), moderate (2), significant (3) and severe (4), in the following categories: neutrophil infiltration, interstitial edema, hyperemia, hemorrhage, thickening and necrosis. The sum of the categories was analyzed by the Kruskal-Wallis test $(\mathrm{p}<0.05 ; \mathrm{n}=8)$. The normal group was presented only as reference.

possible therapeutic targets. The CLP method, the most widely used in scientific research, is considered the gold standard (Ercan and Ozdemir, 2015; Cai et al., 2016). In this study, the CLP model was used in rats to investigate the anti-inflammatory effects of Hev b 13 during sepsis.

Subcutaneous administration of $\mathrm{Hev}$ b 13 initially resulted in a significant decline in total and differential leukocytes (Tables 1, 2 and 3). During interpretation of these first results, the hypothesis was raised that leukopenia could have been caused by their redistribution from the vascular compartment to the injury site. Leukocytes combat localized infection, preventing systemic dissemination. By contrast, their adherence to the endothelium causes microvessel narrowing, directly influencing blood flow and modulating oxygen supply (Cohen, 2002). These cell infiltrates also release pro-inflammatory cytokines, where TNF- $\alpha$ is especially influential in recruiting more neutrophils, and may directly affect tissue via the accumulation of lysosomal enzymes and free radicals (Hansen et al., 2011; Stearns-Kurosawa et al., 2011).

Next, analysis of the other results, with a decrease in TNF- $\alpha$ and IL- 6 production associated with a rise in plasma IL-10 and IL-4 (Figure 1) and lung tissue (Figure 2), shows that $\mathrm{Hev}$ b 13 exerted dose-dependent anti-inflammatory effects, likely suppressing the release of leukocytes from the bone marrow or lymphoid organs into the blood. In line with the other findings, the administration of $\mathrm{Hev}$ b 13 attenuated the morphopathological lesions found in lungs during sepsis, including neutrophil infiltration, edema and alveolar thickening (Figure 3).

The inflammatory response in sepsis is characterized by excess production of pro-inflammatory cytokines, primarily TNF- $\alpha$, IL- $1 \beta$ and IL- 6 , such that production of anti-inflammatory mediators is not adequately counterbalanced, mainly in the initial phase (Sagy et al., 2013). This imbalance in cytokine production causes endothelial lesions, pulmonary edema and hemorrhage, and may evolve to terminal complications associated with sepsis (MODS) (Zhou et al., 2015). The association between higher concentrations of pro-inflammatory cytokines in the acute phase of sepsis and the unfavorable evolution of organic dysfunctions have been studied and confirmed (Chien et al., 2011; Machado et al., 2011; Saad et al., 2016). Interfering in the excessive production of these mediators during the acute phase of sepsis, as occurred in our study, may result in better prognosis of the disease. Treatments with pro-inflammatory cytokine inhibitors (antibodies, soluble receptors and anti-inflammatory cytokines) have provided advantages in the experimental models of severe sepsis (Opal et al., 1997; Lomas-Neira et al., 2012).

Studies with Hev b 13 have demonstrated the biological ability of reducing pro-inflammatory cytokine production and increasing anti-inflammatory production of cytokines such as IL-10. The same protein also significantly improved the clinical and histopathological condition of arthritis and colitis in experimental models, suggesting anti-inflammatory potential (Teixeira et al., 2012a, b). Thus, the immunomodulating effects of the Hev b 13 fraction in rats with sepsis, induced by injection of Acinetobacter baumannii into the peritoneal cavity after lesion in the pancreas and stomach, were investigated during earlier experiments in our laboratory, with a notable increase in IL-10 production and reduction of IL-6 in lung tissue (data not published). Our results corroborate evidence showing that the Hev b 13 protein acts as an anti-inflammatory, 
and to date no studies have been published regarding its effects on sepsis.

IL-10 is the most important anti-inflammatory cytokine found in human immune response (Opal and De Palo, 2000). In addition to negatively modulating Th1, it deactivates the synthesis of pro-inflammatory cytokines from monocytes/macrophages and inhibits cell migration (Hong et al., 2014). The protective effects of IL-10 in experimental sepsis may be associated with the sepsis induction model (CLP or LPS- lipopolysaccharide) and intervention time (Kalechman et al., 2002), but in general, treating septic rats with IL-10 delays lethality, increases survival, and extends the therapeutic window (Remick et al., 2000). By contrast, IL-10 administered after septic shock, irrespective of induction methodology, may have limited therapeutic benefits, given the prolonged state of immunosuppression in the late phase of the disease (Latifi et al., 2002). Interleukin-4, the dominant mediator of Th2 profile, is known to play an important role in the pathogenesis of sepsis, but its precise function during the course of the disease remains unknown (Schulte et al., 2013). Preliminary clinical investigations demonstrated the potent anti-inflammatory action of IL-4, with a significant increase in the survival of septic mice exposed to lethal doses of LPS (Baumhofer et al., 1998).

Progressive interstitial edema in the pulmonary vascular endothelium is inherent to the inflammatory process during sepsis, where pro-inflammatory cytokines contribute significantly to this process (Matthay et al., 2012). In this study, a single dose of Hev b 13, administered 6 hours after CLP surgery, was able to attenuate pulmonary lesions caused by sepsis at different points in time. This could be explained by the reduced amount of TNF and IL- 6 in the lung tissue of animals. This finding is relevant, given that most patients with severe sepsis develop acute pulmonary lesions (APL), with high morbidity and mortality indices (Gokcinar et al., 2013; Ates et al., 2015).

\section{Conclusions}

Our results show that Hev b 13 displays antiinflammatory properties in sepsis associated with a reduction in TNF- $\alpha$ and IL-6, as well as a simultaneous increase in IL4 and IL-10 at both the systemic and tissue level. It also exhibits protective effects against sepsis-related pulmonary organic dysfunctions. Thus, we suggest that dose-dependent treatment with Hev b 13 has therapeutic potential for sepsis during the acute phase. Manipulating immunoregulators will benefit patients with sepsis, and will likely be increasingly used in clinical practice as studies progress. New experiments should be conducted using multiple doses of Hev b 13 involving different organs to elucidate their immunocellular effects on sepsis.

\section{References}

ABD EL-LATIF, A.A., SAYED, A.A., SOLIMAN, A.M. and FAHMY, S.R., 2016. Exploration of the therapeutic potential effect of Sepia officinalis in animal model of sepsis induced by cecal ligation and puncture. Injury, vol. 47, no. 12, pp. 2709-2717. http://dx.doi.org/10.1016/j.injury.2016.10.003. PMid:27743598.

ATES, I., DOGAN, N., AKSO, M., HALICI, Z., GÜNDOGDU, C. and KELES, M.S., 2015. The protective effects of IgMenriched immunoglobulin and erythropoietin on the lung and small intestine tissues of rats with induced sepsis: Biochemical and histopathological evaluation. Pharmaceutical Biology, vol. 53, no. 1, pp. 78-84. PMid:25243880. http://dx.doi.org/10.3109 $/ 13880209.2014 .910535$.

BAUMHOFER, J.M., BEINHAUER, B.G., WANG, J.E., BRANDMEIER, H., GEISSLER, K., LOSERT, U., PHILIP, R., AVERSA, G. and ROGY, M.A., 1998. Gene transfer with IL-4 and IL-13 improves survival in lethal endotoxemia in the mouse and ameliorates peritoneal macrophages immune competence. European Journal of Immunology, vol. 28, no. 2, pp. 610-615. PMid:9521071.

CAI, B., LUO, Y.L., WANG, S.J., WEI, W.Y., ZHANG, X.H., HUANG, W., LI, T., ZHANG, M., WU, N., ROODRAJEETSING, G. and ZHANG, S., 2016. Does citrulline have protective effects on liver injury in septic rats? BioMed Research International, vol. 2016, p. 1469590. http://dx.doi.org/10.1155/2016/1469590. PMid:27195281.

CHIEN, W.S., CHEN, Y.H., CHIANG, P.C., HSIAO, H.W., CHUANG, S.M., LUE, S. and HSU, C., 2011. Suppression of autophagy in rat liver at late stage of polymicrobial sepsis. Shock, vol. 35, no. 5, pp. 506-511. PMid:21263383. http://dx.doi. org/10.1097/SHK.0b013e31820b2f05.

COHEN, J., 2002. The immunopathogenesis of sepsis. Nature, vol. 420, no. 6917, pp. 885-891. PMid:12490963. http://dx.doi. org/10.1038/nature01326.

ERCAN, M. and OZDEMIR, S., 2015. The contribution to studies of the effect of $\beta$-glucan on plasma viscosity in a rat sepsis model. Medical Science and Discovery, vol. 2, no. 1, pp. 148-153. http:// dx.doi.org/10.17546/msd.35215.

GOKCINAR, D., ERGIN, V., CUMAOGLU, A., MENEVSE, A. and ARICIOGLU, A., 2013. Effects of ketamine, propofol, and ketofol on proinflammatory cytokines and markers of oxidative stress in a rat model of endotoxemia-induced acute lung injury. Acta Biochimica Polonica, vol. 60, no. 3, pp. 451-456. PMid:24020061.

GOMES, A.P., MIGUEL, P.S.B., ALVES, D.L.S., INOUE, V.H., OLIVEIRA, A.P., CERQUEIRA, F.R., LOPES, T.C.C., SANTANA, L.A., GELLER, M. and SIQUEIRA-BATISTA, R., 2016. Pro-inflammatory cytokines in sepsis: biological studies and prospects from in silico research. Biological Systems, vol. 5, no. 158. http://dx.doi.org/10.4172/2329-6577.1000158.

HANSEN, J.D., VOJTECH, L.N. and LAING, K.J., 2011. Sensing disease and danger: a survey of vertebrate PRRs and their origins. Developmental and Comparative Immunology, vol. 35, no. 9, pp. 886-897. PMid:21241729. http://dx.doi.org/10.1016/j. dci.2011.01.008.

HONG, T.H., CHANG, C.H., KO, W.J., LIN, C.F., LIU, H.H., CHOW, L.P., HUANG, C.T., YU, S.L. and CHEN, Y.S., 2014. Biomarkers of early sepsis may be correlated with outcome. Journal of Translational Medicine, vol. 12, no. 146, pp. 146. PMid:24886652. http://dx.doi.org/10.1186/1479-5876-12-146.

IWASHYNA, T.J., NETZER, G., LANGA, K.M. and CIGOLLE, C., 2012. Spurious inferences about long-term outcomes: the case of severe sepsis and geriatric conditions. American Journal of Respiratory and Critical Care Medicine, vol. 185, no. 8, pp. 835-841. PMid:22323301. http://dx.doi.org/10.1164/rccm.201109-1660OC. 
KALECHMAN, Y., GAFTER, U., GAL, R., RUSHKIN, G., YAN, D., ALBECK, M. and SREDNI, B., 2002. Anti-IL-10 therapeutic strategy using the immunomodulator AS101 in protecting mice from sepsis-induced death: dependence on timing of immunomodulating intervention. Journal of Immunology, vol. 169, no. 1, pp. 384-392. PMid:12077268. http://dx.doi.org/10.4049/jimmunol.169.1.384.

KAUKONEN, K.M., BAILEY, M., SUZUKI, S., PILCHER, D. and BELLOMO, R., 2014. Mortality related to severe sepsis and septic shock among critically ill patients in Australia and New Zealand, 2000-2012. Journal of the American Medical Association, vol. 311, no. 13, pp. 1308-1316. PMid:24638143. http://dx.doi. org/10.1001/jama.2014.2637.

LATIFI, S.Q., O'RIORDAN, M.A. and LEVINE, A.D., 2002. Interleukin-10 controls the onset of irreversible septic shock. Infection and Immunity, vol. 70, no. 8, pp. 4441-4446. PMid:12117955. http://dx.doi.org/10.1128/IAI.70.8.4441-4446.2002.

LOMAS-NEIRA, J., PERL, M., VENET, F., CHUNG, C.S. and AYALA, A., 2012. The role and source of tumor necrosis factoralpha in hemorrhage-induced priming for septic lung injury. Shock, vol. 37, no. 6, pp. 611-620. PMid:22552013. http://dx.doi. org/10.1097/SHK.0b013e318254fa6a

MACHADO, F.R., SANCHES, L.C., AZEVEDO, L.C.P., BRUNIALTI, M., LOURENÇO, D., NOGUTI, M.A. and SALOMÃO, R., 2011. Associação entre a evolução da disfunção orgânica e as concentrações de citocinas na fase inicial do choque séptico. Revista Brasileira de Terapia Intensiva, vol. 23, no. 4, pp. 426-433. PMid:23949455. http://dx.doi.org/10.1590/S0103507X2011000400006.

MATSUDA, N. and HATTORI, Y., 2006. Systemic inflammatory response syndrome (SIRS): molecular pathophysiology and gene therapy. Journal of Pharmacological Sciences, vol. 101, no. 3, pp. 189-198. PMid:16823257. http://dx.doi.org/10.1254/jphs. CRJ06010X

MATTHAY, M.A., WARE, L.B. and ZIMMERMAN, G.A., 2012. The acute respiratory distress syndrome. The Journal of Clinical Investigation, vol. 122, no. 8, pp. 2731-2740. PMid:22850883. http://dx.doi.org/10.1172/JCI60331.

OPAL, S.M. and DEPALO, V.A., 2000. Anti-inflammatory cytokines. Chest, vol. 117, no. 4, pp. 1162-1172. PMid:10767254. http://dx.doi.org/10.1378/chest.117.4.1162.

OPAL, S.M., FISHER JUNIOR, C.J.J., DHAINAUT, J.F., VINCENT, J.L., BRASE, R., LOWRY, S.F., SADOFF, J.C., SLOTMAN, G.J., LEVY, H., BALK, R.A., SHELLY, M.P., PRIBBLE, J.P., LABRECQUE, J.F., LOOKABAUGH, J., DONOVAN, H., DUBIN, H., BAUGHMAN, R., NORMAN, J., DEMARIA, E., MATZEL, K., ABRAHAM, E. and SENEFF, M., 1997. Confirmatory interleukin-1 receptor antagonist trial in severe sepsis: a phase III randomized, double-blind, placebo-controlled multicenter trial. Critical Care Medicine, vol. 25, no. 7, pp. 1115-1124. PMid:9233735. http:// dx.doi.org/10.1097/00003246-199707000-00010.

RANIERI, V.M., THOMPSON, B.T., BARIE, P.S., DHAINAUT, J.F., DOUGLAS, I.S., FINFER, S., GARDLUND, B., MARSHALL, J.C., RHODES, A., ARTIGAS, A., PAYEN, D., TENHUNEN, J., AL-KHALIDI, H.R., THOMPSON, V., JANES, J., MACIAS, W.L.,
VANGEROW, B. and WILLIAMS, M.D., 2012. Drotrecogin Alfa (activated) in adults with septic shock. The New England Journal of Medicine, vol. 366, no. 22, pp. 2055-2064. PMid:22616830. http://dx.doi.org/10.1056/NEJMoa1202290.

REMICK, D.G., NEWCOMB, D.E., BOLGOS, G.L. and CALL, D.R., 2000. Comparison of the mortality and inflammatory response of two models of sepsis: lipopolysaccharide versus cecal ligation and puncture. Shock, vol. 13, no. 2, pp. 110-116. PMid:10670840. http://dx.doi.org/10.1097/00024382-200013020-00004.

SAAD, D.Y., BAIOMY, A.A. and MANSOUR, A.A., 2016. Antiseptic effect of sea cucumber (Holothuria atra) against multiorgan failure induced by sepsis: Molecular and histopathological study. Experimental and Therapeutic Medicine, vol. 12, no. 1, pp. 222-230. PMid:27347042. http://dx.doi.org/10.3892/etm.2016.3321.

SAGY, M., AL-QAQAA, Y. and KIM, P., 2013. Definitions and pathophysiology of sepsis. Current Problems in Pediatric and Adolescent Health Care, vol. 43, no. 10, pp. 260-263. PMid:24295606. http://dx.doi.org/10.1016/j.cppeds.2013.10.001.

SCHULTE, W., BERNHAGEN, J. and BUCALA, R. 2013. Cytokines in Sepsis: potent immunoregulators and potential therapeutic targets- an updated view. Mediators of Inflammation, vol. 2013, pp. 165974. http://dx.doi.org/10.1155/2013/165974. PMid:23853427.

SHANKAR-HARI, M., PHILLIPS, G.S., LEVY, M.L., SEYMOUR, C.W., LIU, V.X., DEUTSCHMAN, C.S., ANGUS, D.C., RUBENFELD, G.D. and SINGER, M., 2016. Developing a new definition and assessing new clinical criteria for septic shock for the third international consensus definitions for sepsis and septic shock (sepsis-3). Journal of the American Medical Association, vol. 315, no. 8, pp. 775-787. PMid:26903336. http:// dx.doi.org/10.1001/jama.2016.0289.

STEARNS-KUROSAWA, D.J., OSUCHOWSKI, M.F., VALENTINE, C., KUROSAWA, S. and REMICK, D.G., 2011. The pathogenesis of sepsis. Annual Review of Pathology, vol. 6, no. 1, pp. 19-48. PMid:20887193. http://dx.doi.org/10.1146/ annurev-pathol-011110-130327.

TEIXEIRA, L.B., EPIFÂNIO, V.L.A.A., LACHAT, J.J., FOSS, N.T. and COUTINHO-NETTO, J., 2012a. Oral treatment with Hev b 13 prevents experimental arthritis in mice. Clinical and Experimental Immunology, vol. 168, no. 3, pp. 285-290. PMid:22519591. http:// dx.doi.org/10.1111/j.1365-2249.2012.04582.x.

TEIXEIRA, L.B., EPIFÂNIO, V.L.A.A., LACHAT, J.J., FOSS, N.T. and COUTINHO-NETTO, J., 2012b. Oral treatment with Hev b 13 ameliorates experimental colitis in mice. Clinical and Experimental Immunology, vol. 169, no. 1, pp. 27-32. PMid:22670775. http:// dx.doi.org/10.1111/j.1365-2249.2012.04589.x.

WARD, P.A., 2011. Immunosuppression in sepsis. Journal of the American Medical Association, vol. 306, no. 23, pp. 2618-2619. PMid:22187286. http://dx.doi.org/10.1001/jama.2011.1831.

ZHOU, L., GAO, M., XIAO, Z., ZHANG, J., LI, X. and WANG, A., 2015. Protective effect of astaxanthin against multiple organ injury in a rat model of sepsis. The Journal of Surgical Research, vol. 195 , no. 2 , pp. 559-567. PMid:25770740. http://dx.doi. org/10.1016/j.jss.2015.02.026. 